\title{
TUBERCULOMA OF THE EYE
}

BY

G. E. DodDS, M.B.

WEST AFRICAN MEDICAL SERVICE

In this case the disease had reached a stage which would rarely be seen in Europe to-day and for this reason may prove of interest. Very little history could be obtained-the patient, a male Yoruba, aged about 12 years was brought to the eye clinic at Lagos with the condition as seen in Fig. 1. He also had advanced spinal caries

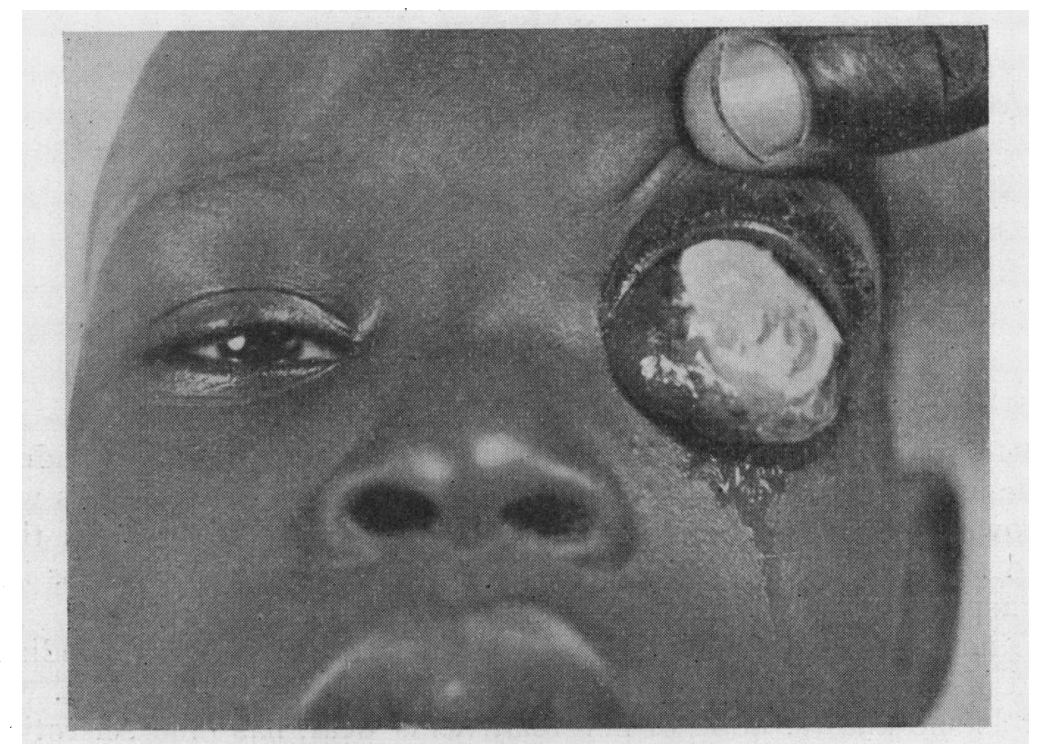

Fig. 1.

with spastic paralysis of the lower extremities. He was admitted to the hospital and treated by extension and tonics.

His condition was considered hopeless and it was thought that an early death would put an end to his troubles. His mother stated that about two years previously he complained of pain in the back and later that a swelling had developed on the back; his legs then became powerless and finally the eye trouble started. No other details of the course or the appearance of the disease could be obtained. After three months treatment the patient's general condition had improved and the tumour had diminished in sizesee Fig. 2-photograph taken three months after Fig. 1.

The globe was enucleated and the pathologist, Dr. D. A. Cannon reported as follows:- 


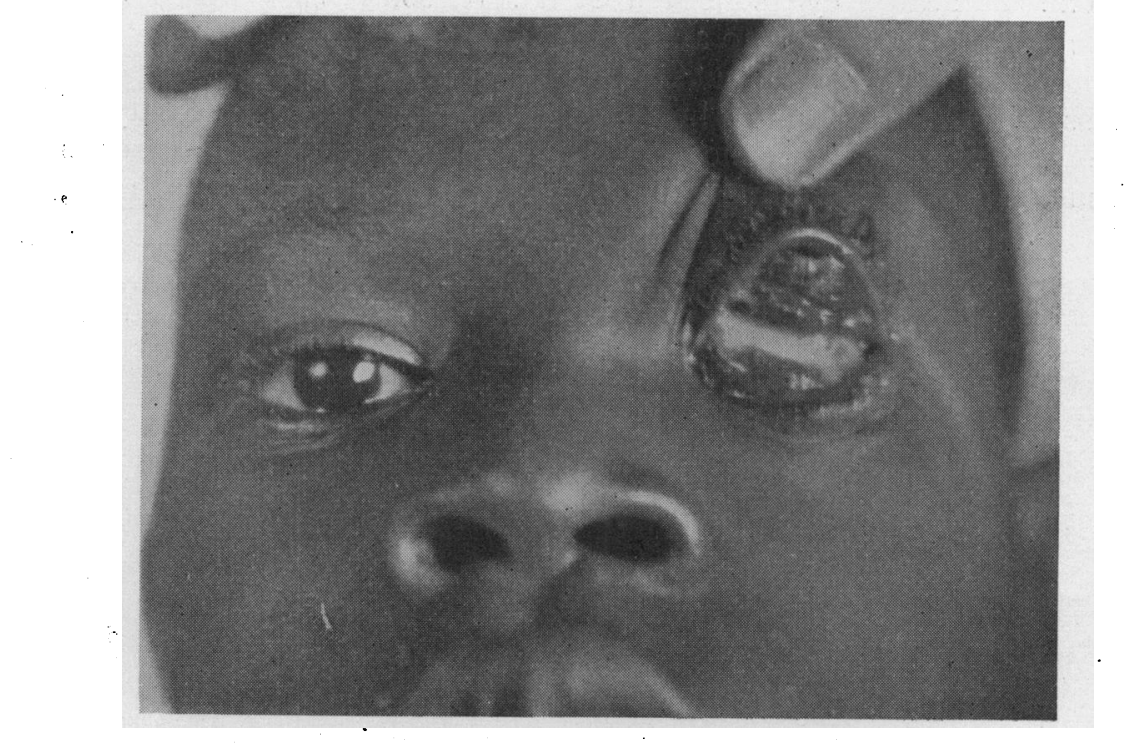

FIG. 2.

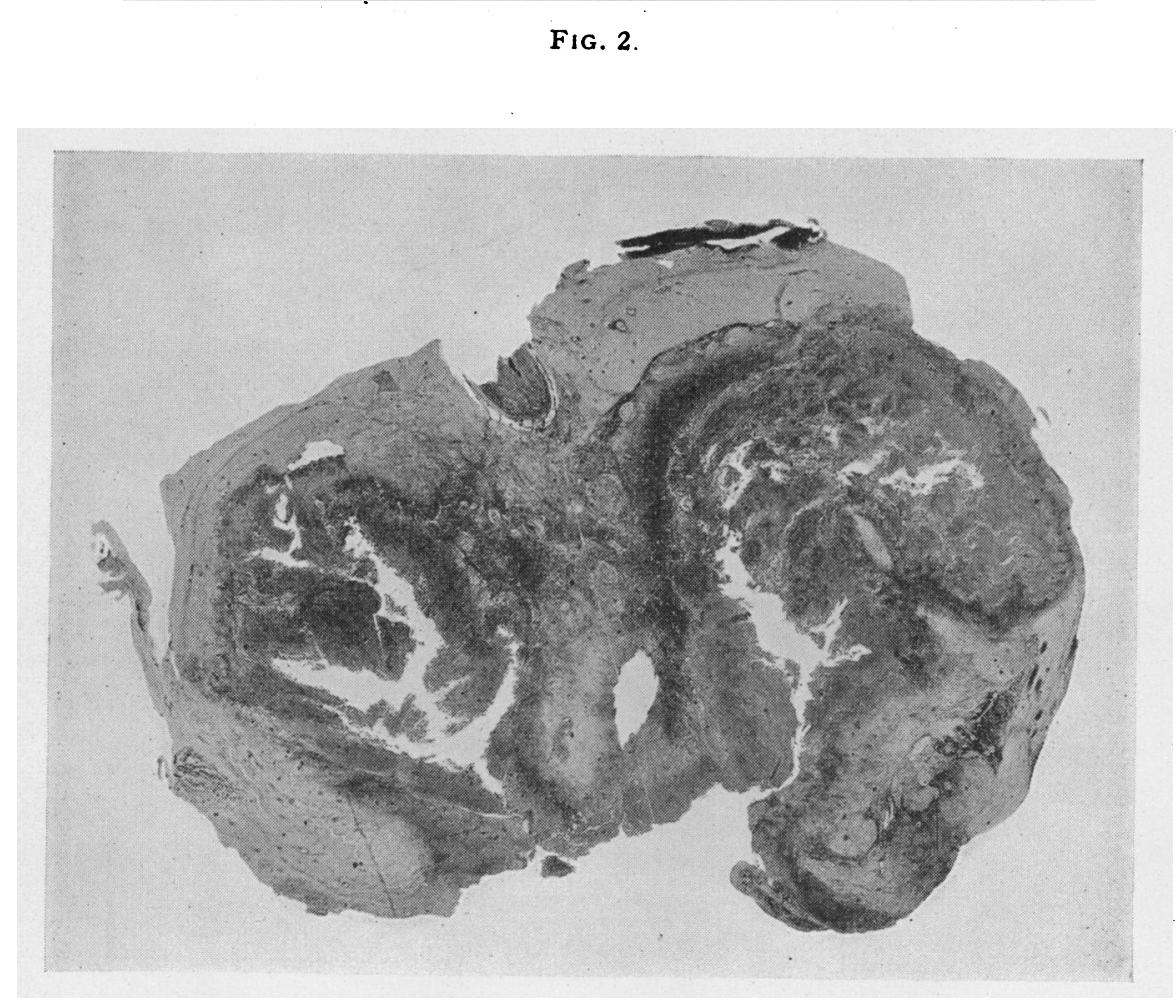

FIG: 3.

w

.

응 
The enucleated eye consisted of a soft, solid mass which bore little or no resemblance to an eye-ball; the remnant of the lens and cornea were still visible, but for the rest, the organ consisted of a mass of necrotic tissue, bathed in creamy, yellow pus; no cavity of the eye persisted. Sections revealed merely a mass of caseous tissue, in which were numerous typical large tuberculous giant-cells,

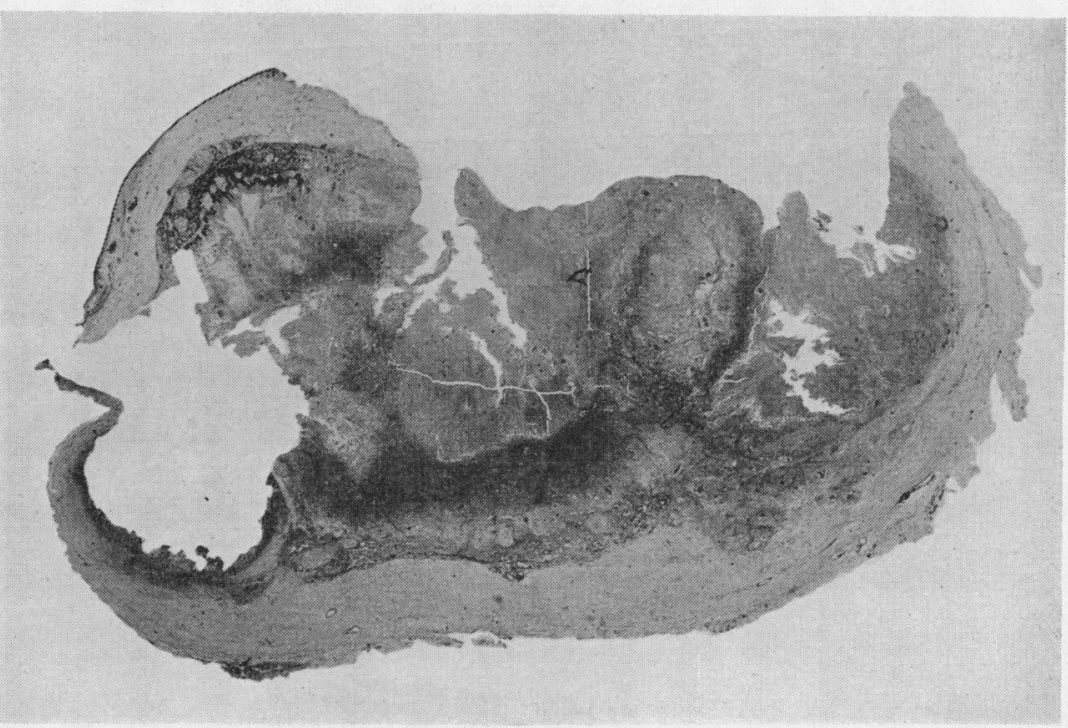

FIG. 4.

FIG. 5 . 
the process of caseation had involved all tissues of the organ (see Fig. 3).

Fig. 4 shows a part of the ciliary body, which is broken up and largely destroyed; small foci of caseation, with giant-cells can be seen to be invading the several layers of the sclera (see Fig. 6, H.P. of Fig. 4). Direct smears made from the enucleated eye failed to

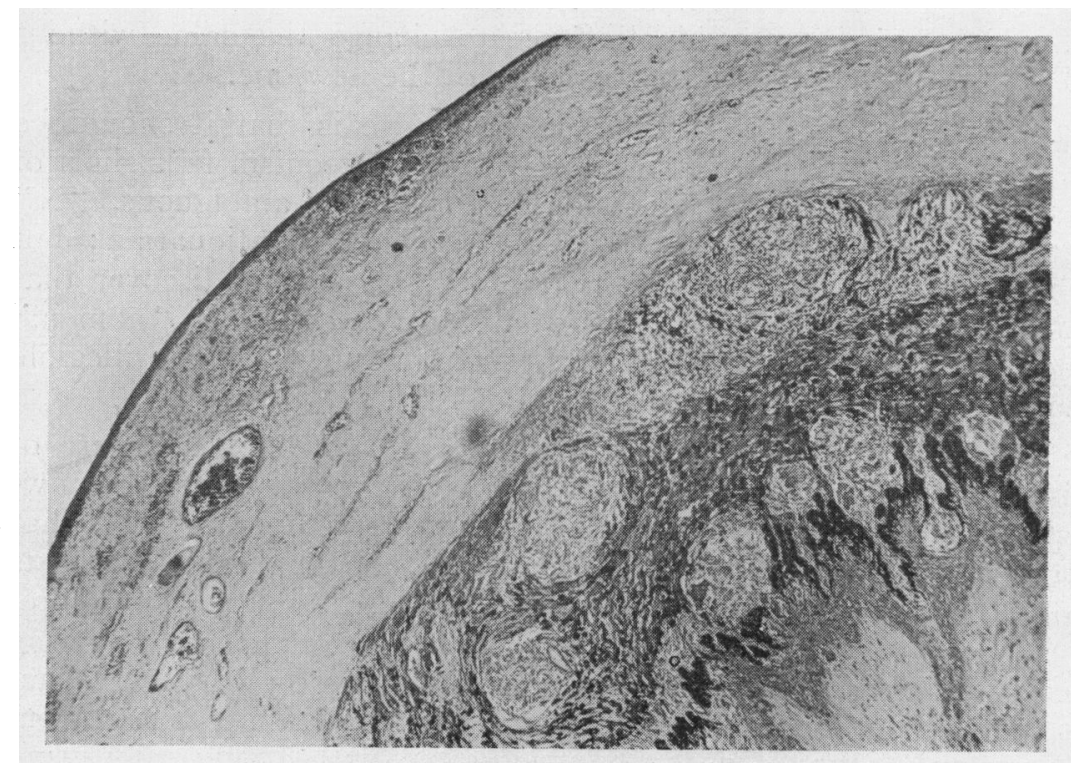

FIG. 6.

reveal tubercle bacilli. but a guinea-pig, which was inoculated with pus from the eye, was killed after seven weeks, and showed typical tuberculous lesions which contained acid fast bacilli.

I wish to thank the Director of Medical Services, Nigeria, for permission to publish these notes; $\mathrm{Mr}$. Knight of the Nigerian Laboratory Service for photographs and the Pathologist, Dr. D. A. Cannon.

\section{ANNOTATIONS \\ "WHAT'S IN A NAME?" \\ "What is your Name?" " $\mathrm{N}$ or M." \\ "Who gave you this Name." "My Godfathers and \\ Godmothers in my Baptism." The Catechism}

The responsibility of godparents in naming children is great. It is clearly a risky procedure to call a girl "Prudence" or 